\author{
Emilia Leszkowicz
}

Uniwersytet Gdański

\title{
Selected neuroplastic effects of cognitive training in aging in MRI/fMRI studies
}

\author{
Wybrane neuroplastyczne efekty treningu kognitywnego \\ $\mathrm{w}$ wieku podeszłym $\mathrm{w}$ badaniach MRI/fMRI
}

Streszczenie. Szereg badań sugeruje, że można przeciwdziałać i zapobiegać utracie zdolności kognitywnych (poznawczych) u ludzi w starszym wieku oraz że ryzyko upośledzenia procesów poznawczych i demencji może być u nich zredukowane. Trening kognitywny daje takie szanse, stwarzając możliwości modyfikowania umiejętności poznawczych oraz leżących u ich podstaw procesów neuronalnych w wieku zaawansowanym. W niniejszej pracy zaprezentowano przykłady zmian neuroplastycznych w mózgu wywołane wielowymiarowym treningiem kognitywnym u osób w okresie zdrowego starzenia się oraz z upośledzeniem procesów poznawczych, rejestrowane metodami obrazowania funkcji mózgu (MRI/fMRI). Efekty treningu kognitywnego obserwowane były zarówno na poziomie behawioralnym, jak i nerwowym, co podkreśla wagę interwencji terapeutycznych skierowanych na wielorakie aspekty stylu życia jako możliwych strategii podtrzymania i poprawy statusu poznawczego jednostki w wieku zaawansowanym. Efekty takich interwencji mogą przynieść znaczące korzyści w aspekcie zdrowia publicznego, szczególnie w erze starzejących się społeczeństw.

Słowa kluczowe: wiek podeszły, trening kognitywny, neuroplastyczność mózgu, MRI/fMRI

Summary. Several lines of research suggest that the loss of cognitive faculties in older people can be prevented and the risk of cognitive decline and dementia can be reduced. Cognitive training offers potential to modify cognitive abilities and their neural basis which can extend into advanced age. Examples of neuroplastic changes in the brain induced by multi-domain cognitive intervention and assessed by MRI/fMRI method in healthy aging and in people with cognitive impairment are presented. Cognitive training effects were observed both at behavioural and neural levels, which underlines the importance of interventions aimed at multiple lifestyle factors as possible strategies to support and improve cognitive status in advanced age. Effects of such interventions may result in considerable gains in terms of public health, especially in the face of aging societies.

Keywords: elderly, cognitive training, neuroplasticity, MRI/fMRI 


\section{Introduction}

Deterioration of cognitive abilities including mental activities such as perceiving, learning, thinking, reasoning, understanding and remembering accompanies normal aging. To enhance cognitive functions that support accomplishment of everyday tasks and thus independent living in advanced age, cognitive training can be implemented (Rebok et al., 2014). Cognitive training, which is a guided practice on tasks designed to improve particular cognitive abilities, promotes various neuroplastic mechanisms in the brain that can be conserved well into advanced age (Boyke et al., 2008). Neuroplasticity occurs both at structural and functional levels, and can include alterations in grey matter volume (Engvig et al., 2014), white matter integrity (Cao X et al., 2016), cerebral blood flow (Maffei et al., 2017), brain activity (Maffei et al,. 2017), and functional connectivity (Cao W et al., 2016). In this article, I present a few examples of structural and functional neuroplastic changes which accompanied improvements in cognitive performance in healthy aging and mild forms of cognitive impairment, and which were assessed with MRI/fMRI method, a non-invasive brain imaging method frequently used in cognitive and experimental psychology (e.g. Leszkowicz et al., 2017). Intrinsic capacity of the human brain for such neuroplastic changes justifies multi-domain cognitive interventions, whose potential benefits can be substantial in terms of public health.

\section{Structural changes involving grey matter volume}

Common targets in cognitive training research are the hippocampus and cerebral cortex. The hippocampus located in the medial temporal lobe is a brain structure critically associated with learning and memory which engage theta rhythm in animals (Leszkowicz, 2007), and is particularly vulnerable to damage in the early stages of dementia and Alzheimer's disease (Sabuncu et al., 2011). The cerebral cortex is implicated in the processing of a wide range of cognitive information (e.g. Takeuchi et al., 2017). The hippocampus and cortex, succumb to atrophy in the affected patients (Sabuncu et al., 2011).

In a study by Engvig and co-workers (2014), two groups of volunteers of mean age 61 years participated in cognitive training: healthy adults and patients diagnosed with subjective memory impairment (SMI). Neuropsy- 
chological tests were used to check for specified exclusions criteria and provide clinical characteristics of the subjects.

SMI patients underwent memory training $(n=19)$. Healthy adults were randomly divided into two groups: one received the same training as SMI subjects $(n=22)$ and one served as a no-contact control $(n=20)$. Memory training lasted 8 weeks with supervised 90-min classes once a week, and included homework assignments. The main aim of the program was to improve verbal recall memory by method of loci training (Bower, 1970). Training also offered an arena for social interactions. Verbal memory performance (The California Verbal Learning Test) and longitudinal grey matter changes across the cortex and hippocampus (MRI) were assessed approx. 1 week before (baseline) and after training.

a
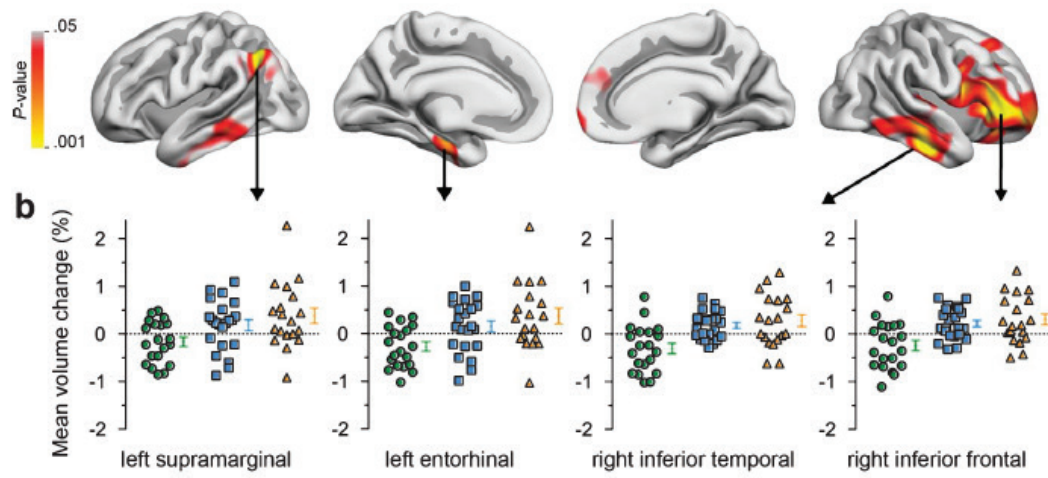

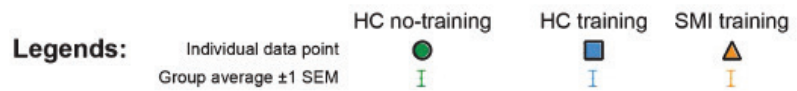

Fig. 1. a) Longitudinal increases in cortical volume in SMI- and healthy-training groups following training. Four significant clusters of increased volumes were identified (GLM-analysis). P-value maps colour-coded in red-yellow gradient are overlaid on template cortical Fig. 1. a) Longitudinal increases in cortical volume in SMI- and healthy-training groups following training. Four significant clusters of increased volumes were identified (GLM-analysis). P-value maps color-coded in red-yellow gradient are overlaid on template cortical surfaces. b) Average volume change within each cluster is plotted for each participant together with group means ( \pm 1 SE). SMl, participants with subjective memory impairment; HC, healthy subjects. (Reproduced with permission from [Engvig et al., 2014]) 

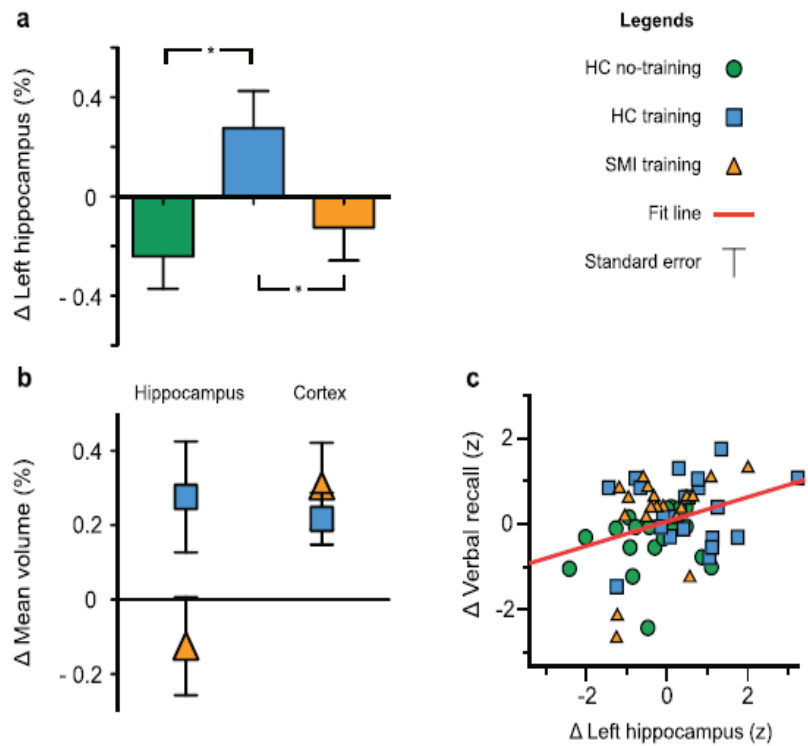

Fig. 2. a) Memory training was associated with increased hippocampal volume in healthy-training group. The bar plot shows group averages ( \pm 1 SE) of hippocampal volume change. b) Differential effects of memory training on frontal cortical and hippocampal plasticity in SMl group; comparable cortical plasticity, but significantly lower hippocampal plasticity in SMI compared with healthy-training group. The plot shows average ( $\pm 1 \mathrm{SE}$ ) grey matter volume changes in the left hippocampus and right prefrontal cortex. c) Hippocampal volume change correlated with verbal recall improvement across all participants. A linear fit line across groups is shown in red. (Reproduced with permission from [Engvig et al., 2014])

Following memory training, both training groups significantly improved their recall performance compared to the baseline. Cortical grey matter increases were observed in both training groups compared with controls, and were of similar extent (Fig. 1, 2b). Clusters of significantly increased cortical volume were found in both hemispheres in the temporal (the entorhinal cortex and inferior temporal gyrus), parietal (the supramarginal gyrus) and frontal (the prefrontal cortex) lobes. The volume of the left hippocampus increased following training only in healthy subjects compared with controls; in the same time, in SMI group training slightly reduced the hippocampal grey matter loss (Fig. 2a). Hippocampal but not cortical volume increase correlated with recall improvement across all participants (Fig. 2c). Mechanisms underlying grey matter volume changes are not ful- 
ly understood but they might include dendritic spine growth and dendritic branching, axonal buttons growth and axon sprouting, formation of new synapses, neurogenesis and glial changes (Zatorre et al., 2012).

\section{Functional changes involving neuronal activity alterations}

In another study, where cognitive training was combined with physical exercise, the influence of training on cognitive decline and brain activity was assessed (Maffei et al., 2017). Elderly participants aged 65-89 years and diagnosed with mild cognitive impairment $(\mathrm{MCI})$ were randomly assigned to the multi-domain training group $(n=55)$ or no training group (controls, $n=58$ ). Screening evaluation was performed with an array of tests and a questionnaire, and specified exclusion criteria, including moderate or severe dementia and depression, were employed in the study.

Training patients were assigned to smaller classes $(n=7-10)$ and given two 60-min supervised cognitive training sessions per day, 3 times a week for 7 months. The training aimed at stimulating multiple cognitive functions such as acoustic and visual attention, visual, spatial, verbal and affective memory, memory for terms and meanings, orientation, imagination, and logic. The whole group was given 60-min music therapy (listening, singing, playing instruments) once a week, and watched a film followed by a discussion once a month. The intervention fostered social interactions. Physical training consisted of supervised 60-min aerobic exercises 3 times a week for 7 months. No training subjects continued with their usual life routine. Brain activity assessed during fMRI scanning was elicited by a cognitive task, namely a visuo-spatial attention task (tracking dots). The extent of cognitive decline from the pre-training baseline was assessed at the end of 7 months of training or usual life with Alzheimer's Disease Assessment Scale-cognitive (ADAS-Cog). Brain activity elicited by the cognitive task within task-related brain regions also was measured before (baseline) and after 7-month training.

The combined cognitive-physical intervention reduced the extent of cognitive decline with respect to controls. The global cognitive status was significantly improved at the end of 7-month training in training subjects and deteriorated in no training controls with respect to the baseline. Training had no effect on the accuracy of the task performed during fMRI scanning (Fig. 3a). Performance level remained equal between pre- and posttraining periods in both groups. Yet, while training subjects showed no 
change of activity in task-related brain regions as compared to the pre-training baseline, increased activation was observed in the no training group (the left middle temporal region, intraparietal sulcus, and premotor cortex) (Fig. $3 c, d)$. Thus, training subjects seemed to achieve the same performance level engaging less neural resources, which suggested that neural efficiency was preserved in training adults and diminished in controls. Training group was likely more skilled and more efficient with dealing with the task and, therefore, showed less brain activation in task-related regions (see Bernardi et al., 2013).
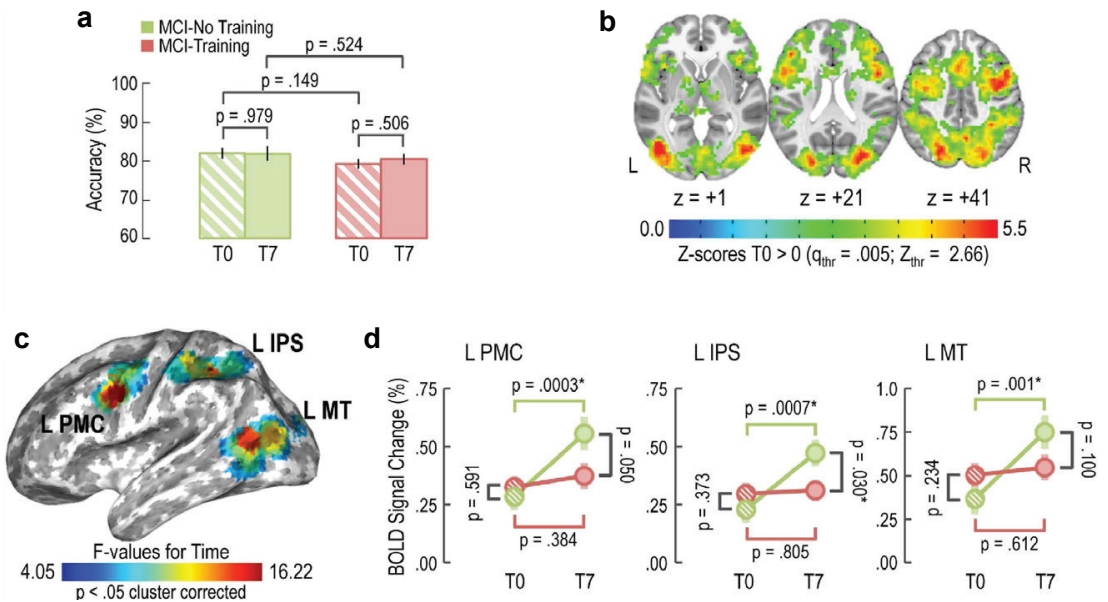

Fig. 3. Training maintained neural efficiency as measured by task-related fMRI. a) No effect of training on task accuracy was evident for MCl-training and MCl-no training subjects. b) Task-related regions of interest obtained by pooling MCl-training and MCl-no training subjects together (pre-training baseline). c) Effects of training on brain activity: brain regions showing a significant effect of training (prevs post-training). d) MCl-no training subjects showed an increase of brain activity (BOLD signal) between pre- and post-training period, while MCl-training subjects did not in task-related brain regions suggesting that training program maintained neural efficiency (post-hoc analysis for each of the regions in section. c) MCl, subjects with mild cognitive impairment; LPMC, left premotor cortex; LIPS, left intraparietal sulcus; LMT, left middle temporal motion-related region; T0, pre-training baseline; $T 7$, after 7-month training. (Reproduced with permission from [Maffei et al., 2017]) 


\section{Functional changes involving functional connectivity of large scale neuronal networks}

Three major large-scale functional networks in the brain (collections of brain regions) have been studied in the context of cognitive training and aging. These networks include the default mode network (DMN) anchored in the medial prefrontal cortex and posterior cingulate cortex, the central executive network (CEN) anchored in the dorsolateral prefrontal cortex and posterior parietal cortex, and the salience network (SN) anchored in the anterior insula and anterior cingulate cortex (Seeley et al., 2007; Uddin et al., 2009). The DMN "by default" is active during wakeful rest when attention is not focused on the outside world, and is driven by self-referential mental activity (e.g. mind wandering, self-monitoring; Mak et al., 2017). The CEN, on the other hand, is active during cognitively demanding mental activity and driven by externally oriented attention (Seeley et al., 2007). It is hypothesized that the SN initiates dynamic switching between the DMN and CEN and mediates between them attention to endogenous and exogenous stimuli, respectively (Bressler, Menon, 2010; Goulden et al., 2014). The SN selects which stimuli are deserving of our attention and is critical for detecting behaviourally relevant stimuli and for coordinating the brain's neuronal resources in response to these stimuli. Disruptions of functional connectivity within and between these networks, including anti-correlation between the DMN and CEN, accompany normal aging (Wu et al., 2011; Joo et al., 2016). Their failure to function properly in its more severe forms can lead to numerous neuropsychiatric disorders, including dementia and Alzheimer's disease (Joo et al., 2016).

The effect of cognitive training on functional connectivity of the DMN, CEN and SN was studied in a group of healthy older adults (Cao et al., 2016). Employed exclusion criteria included obvious cognitive decline and Alzheimer's disease, and serious neurological or psychiatric disorders. The volunteers (65-75 years old) were divided into the training group $(n=23)$ and no training control group $(\mathrm{n}=17)$. Supervised multi-domain cognitive training, which lasted 3 months and consisted of two 60-min sessions in a week, targeted memory, reasoning, and problem-solving strategies using approaches such as visual-spatial map reading, handcraft-making, healthy living, and physical exercises. Both groups attended a lecture about healthy leaving every 2 months. A set of tests was used to evaluate the effects of the intervention on cognitive functions. To examine the effect of training on functional connectivity of the DMN, CEN, and SN resting-state functional images 
(fMRI) were acquired. During fMRI scanning, the subjects were asked to lie with their eyes, not to fall asleep and not to think about anything in particular. All the measurements were conducted before (baseline) and at 1 year after training.
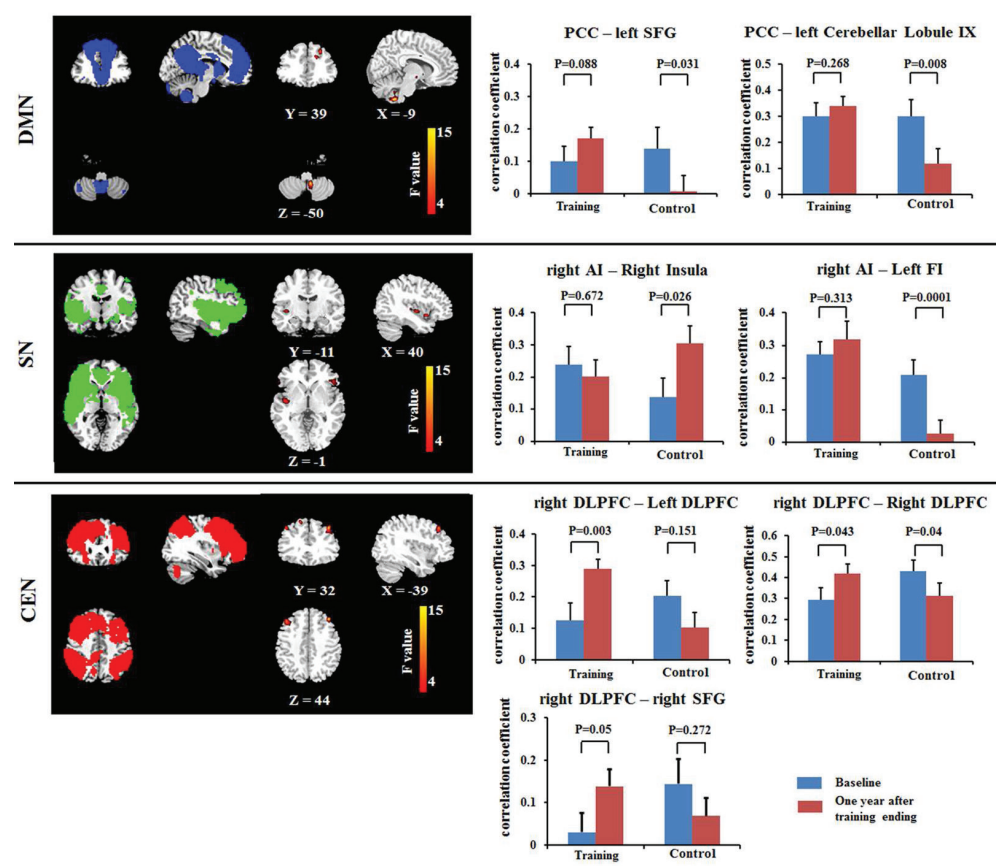

Baseline
One year after
training ending

Fig. 4. Results of resting-state functional connectivity within three large-scale brain networks: the DMN, SN and CEN. Bars at the right show the mean correlation coefficient of significantly altered functional connectivity within the networks in training and control groups at the baseline and 1-year after training ended. Training maintained (in the SN and DMN) or increased (in the CEN) functional connectivity, while in same period it decreased in no-training controls (in the SN and DMN). DMN, default mode network; SN, salience network; CEN, central executive network; PCC, posterior cingulate cortex; SFG, superior frontal gyrus; Al, anterior insula; FI, frontoinsula; DLPFC, dorsolateral prefrontal cortex. The left side of the brain image corresponds to the right side of the subject. (Reproduced with permission from [Cao et al., 2016])

Multi-domain intervention improved performance either significantly or marginally 1 year post-training compared to the baseline. After training, functional connections within the DMN, CEN, and SN were maintained 
or increased in the training group and decreased in the control group (Fig. 4). Moreover, anti-correlated functional connections between the DMN and CEN were maintained or increased following training (data not shown). Authors suggested that changes in resting-state functional connectivity within networks and between them following training might reflected that cognitive training enhanced integration within network and maintenance of segregation between the DMN and CEN.

Overall, the presented data demonstrate that multi-domain cognitive training can mitigate age-related functional and structural alterations in the brain, thereby helping to slow age-related cognitive decline and reduce or delay, and maybe even prevent, dementia. Moreover, efficacy of cognitive intervention often combined with physical exercises is not restricted to healthy aging but may extend to the mild forms of neurodegenerative disorders. This underlines the importance of interventions aimed at multiple lifestyle factors as possible strategies to support and improve cognitive faculties in advanced age. Effects of such interventions may result in considerable gains in terms of public health when the proportion of elderly adults in the population is substantially increasing.

\section{Bibliography}

Bernardi G., Ricciardi E., Sani L., Gaglianese A., Papasogli A., Ceccarelli R., Franzoni F., Galetta F., Santoro G., Goebel R., Pietrini P. (2013), How skill expertise shapes the brain functional architecture: an fMRI study of visuo-spatial and motor processing in professional racing-car and naive drivers, „PloS ONE”, nr 8 (10), art. nr e77764.

Bower G. H. (1970), Analysis of a mnemonic device, „American Scientist”, nr 58, s. 496-510.

Boyke J., Driemeyer J., Gaser C., Buchel C., May A. (2008), Training-induced brain structure changes in the elderly, „Journal of Neuroscience”, nr 28 (28), s. 7031-7035 .

Bressler S. L., Menon V. (2010), Large-scale brain networks in cognition: emerging methods and principles, „Trends in Cognitive Science“, nr 14 (6), s. 277-290.

Cao W., Cao X., Hou C., Li T., Cheng Y., Jiang L., Luo C., Li C., Yao D. (2016), Effects of cognitive training on resting-state functional connectivity of Default Mode, Salience, and Central Executive networks, „Frontiers in Aging Neuroscience”, nr 8, art. nr 70.

Cao X., Yao Y., Li T., Cheng Y., Feng W., Shen Y., Li Q., Jiang L., Wu W., Wang J., Sheng J., Feng J., Li C. (2016), The impact of cognitive training on cerebral white 
matter in community-dwelling elderly: one-year prospective longitudinal Diffusion Tensor Imaging study, „Scientific Reports”, nr 6, art. nr 33212.

Engvig A., Fjell A. M., Westlye L. T., Skaanee N. V., Dale A. M., Holland D., Due-Tønnessen P., Sundseth Ø., Walhovd K. B. (2014), Effects of cognitive training on gray matter volumes in Memory Clinic Patients with subjective memory impairment, „Journal of Alzheimer's Disease”, nr 41 (3), s. 779-791.

Goulden N., Khusnulina A., Davis N. J., Bracewell R. M., Bokde A. L., McNulty J. P., Mullins P. G. (2014), The salience network is responsible for switching between the default mode network and the central executive network: replication from DCM, „Neuroimage”, nr 99, s. 180-190.

Joo S. H., Lim H. K., Lee C. U. (2016), Three large-scale functional brain networks from resting-state functional MRI in subjects with different levels of cognitive impairment, „Psychiatry Investigation”, nr 13 (1), s. 1-7.

Leszkowicz E. (2007), Functional significance of central synchronous rhythms, especially theta rhythm [in Polish], „Sen”, nr 7, s. 25-34.

Leszkowicz E., Linden D. E., Maio G. R., Ihssen N. (2017), Neural evidence of motivational conflict between social values, „Social Neuroscience”, nr 12 (5), s. 494-505 .

Maffei L. et al. (2017), Randomized trial on the effects of a combined physical/cognitive training in aged MCI subjects: the Train the Brain study, „Scientific Reports”, nr 7, art. nr 39471.

Mak L. E., Minuzzi L., MacQueen G., Hall G., Kennedy S. H., Milev R. (2017), The default mode network in healthy individuals: a systematic review and meta-analysis, „Brain Connectivity”, nr 7 (1), s. 25-33.

Rebok G. W., Ball K., Guey L. T., Jones R. N., Kim H. Y., King J. W., Marsiske M., Morris J. N., Tennstedt S. L., Unverzagt F. W., Willis S. L., for the ACTIVE Study Group (2014), Ten-year effects of the advanced cognitive training for independent and vital elderly cognitive training trial on cognition and everyday functioning in older adults, „Journal of the American Geriatrics Society”, nr 62 (1), s. 16-24.

Sabuncu M. R., Desikan R. S., Sepulcre J., Yeo B. T. T., Liu H., Schmansky N. J., Reuter M., Weiner M, W., Buckner R. L., Sperling R. A., Fischl B. (2011), The dynamics of cortical and hippocampal atrophy in Alzheimer Disease, „Archives of Neurology", nr 68 (8), s. 1040-1048.

Seeley W. W., Menon V., Schatzberg A. F., Keller J., Glover G. H., Kenna H., Reiss A. L., Greicius M. D. (2007), Dissociable intrinsic connectivity networks for salience processing and executive control, „Journal of Neuroscience”, nr 27 (9), s. 2349-2356.

Takeuchi N., Mori T., Suzukamo Y., Izumi S. I. (2017), Integration of teaching processes and learning assessment in the prefrontal cortex during a video game teaching-learning task, „Frontiers in Psychology”, nr 7, art. nr 2052. 
Uddin L. Q., Kelly A. M., Biswal B. B., Castellanos F. X., Milham M. P. (2009), Functional connectivity of default mode network components: correlation, anticorrelation, and causality, „Human Brain Mapping”, nr 30 (2), s. 625-637.

Wu J. T., Wu H. Z., Yan C. G., Chen W. X., Zhang H. Y., He Y., Yang H. S. (2011), Aging-related changes in the default mode network and its anti-correlated networks: a resting-state fMRI study, „Neuroscience Letters”, nr 504 (1), s. 62-67.

Zatorre R. J., Fields R. D., Johansen-Berg H. (2012), Plasticity in gray and white: neuroimaging changes in brain structure during learning, "Nature Neuroscience”, nr 15, s. 528-536. 